\section{Fra sans til opplevelse}

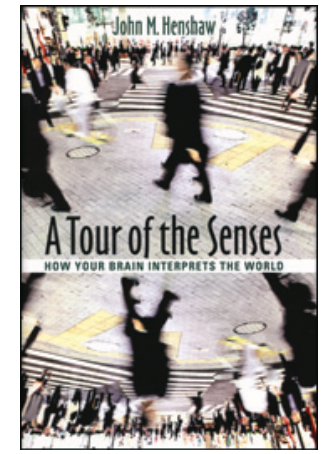

John M. Henshaw

\section{A tour of the senses}

How your brain interprets the world. 272 s, ill. Baltimore, MD: The Johns Hopkins University Press, 2012. Pris USD 30

ISBN 978-1-4214-0436-3

John Henshaw er professor i «Mechanical Engineering» ved Universitetet i Tulsa. I $A$ tour of the senses beskriver han sanseprosessene fra stimulus og sansning til persepsjon.

I første del, Stimulus, gir Henshaw et godt eksempel. Han forteller om en grønn skjorte som han gikk med en gang da han foreleste, og som han først tok på seg i sterkt lys på baderommet. Men da han gikk med den i det fluorescerende lyset i auditoriet, var den rett og slett snørrfarget. Bølgelengden i lyset bestemmer vår oppfatning av omgivelsene.

«Cleaning molecules» benyttes i salgsavdelinger for parfyme. Nesen har luktreseptorer for surt, salt, søtt og bittert. Forfatteren belyser hvorledes vi kan måle sanseinntrykkene. Tekniske forklaringer er for eksempel vellykket til å forklare hva som avgjør om en spesiell bil er god å kjøre («ride quality»).

I den andre delen, Sensation, viser forfatteren hvorledes stimuli ledes gjennom nervene. Mekanismene ved syn og hørsel beskrives i detalj. Henshaw snakker gjerne om forhold som kan relateres til matlaging. Knapt $1 \%$ av de 25000 genene i det humane genom er knyttet til lukt. De kunstige søtstoffene har stor industriell betydning. Senomix er et San Diego-basert foretagende, der smakstestingen er automatisert. Ved genetisk prosjektering av den humane neseslimhinnen fremstilles en bestemt type kunstige smaksreseptorer. Ved å tilsette et fluorescerende stoff og måle intensiteten, kan man analysere styrken av kunstige søtstoffer.

I de to første delene beskriver han den teknisk-kjemiske delen av sansefysiologien. Jeg opplevde disse to delene som praktiske eksempler på hvorledes man ved hjelp av teknisk ingeniørkunst har kommet frem til nye metoder som har med hverdagslivet å gjøre, fra fargetrykk til lukt og smak, fra seismografer til hvorledes vi påvirkes av lys og lyder.

I den tredje delen, Perception, er perspektivet endret. Persepsjon er det sentrale elementet. Henshaw forsøker å forklare hjernefysiologiske mekanismer fra undersøkelser på pasienter med perseptuelle problemer. Denne delen er mindre fullstendig, men vel verdt å lese likevel.

Nevrologisk undersøkelsesmetodikk får god plass. Jill Taylor er en nevroanatom som fikk hjerneslag. I My Stroke of Insight forteller hun om bedring av synsfunksjonen opptil åtte år etter hun hadde hatt slag. Henshaw omtaler dette som «a mystical feeling of oneness with space that most of us could scarcely imagine.» Han bruker Oliver Sacks The Man Who Mistook His Wife for a Hat som en innfallsvinkel til prosopagnosi (manglende evne til å gjenkjenne ansiktstrekk) og automatisert datamaskingjenkjennelse.

Johan A. Aarli

Institutt for klinisk medisin

Seksjon for nevrologi

Universitetet i Bergen

\section{Når mer kjærlighet ikke er svaret}

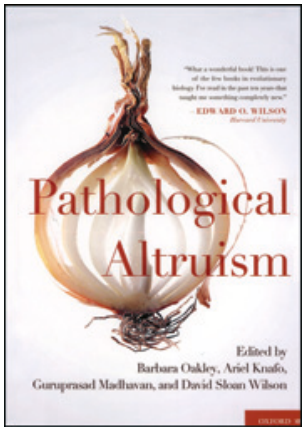

Barbara Oakley, Ariel Knafo, Guruprasad

Madhavan et al, red.

Pathological altruism

465 s, tab, ill. Oxford University Press, 2012.

Pris GBP 35

ISBN 978-0-19-973857-1

Altruisme er definert som en uselvisk og offervillig holdning og handling overfor andre, og er som sådan en høyt verdsatt egenskap i sosiale sammenhenger. Men som svenskene sier, «lagom är best», og derfor finnes det også patologisk altruisme, der det enten er for lite eller for mye av dette personlighetstrekket. For lite altruisme kalles gjerne egoisme, men denne teksten er ikke så opptatt av slike væremåter. Snarere handler den om for mye altruisme, som enten skader dem som er gjenstand for altruismen (ofrene), eller dem som utøver den. Patologisk altruisme rammer enten dem man prøver å hjelpe, eller hjelperen som i sin iver går for langt. Det første handler om å bli kvalt av godhet, og det andre om at godheten går ut over utøveren. Et eksempel på det siste er legen Elisabeth Kübler-Ross, som mange vil huske for Før livet ebber ut (1). Hun forsaket alt ellers i livet for sine døende pasienter, noe hennes mann og barn bebreidet henne for, og som førte til en ganske spesiell form for legepraksis.

Forfatterne kan derfor ha et budskap til kolleger som på ulike måter strekker seg for langt for pasientene sine, men problemet er jo ofte at de ikke er klar over det selv. Derfor er boken kanskje av særlig interesse for psykiatere og kliniske psykologer som driver kollegial veiledning, og for leger som følger Terents' berømte utsagn: «Jeg er et menneske, og intet menneskelig er meg fremmed.»

I de 31 kapitlene nærmer forfatterne seg patologisk altruisme fra psykologisk, psykiatrisk, sosiologisk, nevrobiologisk, kulturelt og evolusjonsmessig perspektiv. Kapitlene varierer fra det strengt empiriske til det personlig impresjonistiske. Tre av redaktørene er amerikanere, og en er fra Israel, mens de 44 forfatterne representerer en bred internasjonal sammensetning. Ingen er imidlertid fra Skandinavia.

Boken er relativt teoritung, og det tok meg atskillige sider før jeg hadde en klar forståelse av hva som er normal, sunn altruisme i motsetning til patologisk altruisme. Til gjengjeld skjønte jeg etter hvert at vi kanskje har et naivt og ureflektert Kardemomme-forhold til normal altruisme: «Man skal ikke plage andre, man skal være god og snill, og for øvrig kan man gjøre hva man vil.» De som ikke har forstått at Moder Teresa var forstyrret eller at Kronprinsen med kravet om mer kjærlighet gir galt tilsvar til ondskapen, blir klokere av denne boken.

\section{Alv A. Dahl}

Oslo universitetssykehus, Radiumhospitalet

\section{Litteratur}

1. Kübler-Ross E. Før livet ebber ut. Oslo: Gyldendal, 1973. 